macroscopic fauna of various Asiatic lakes, with results that are of the greatest interest.

The Asiatic Society of Bengal issues Memoirs in quarto, and Journal and Proceedings in octavo. In the Memoirs, parts ii. to v. of Dr. Annandale's "Zoological Results of a Tour in the Far East" further testify to the author's wonderful activity and versatility, which are known to all zoologists. In these parts he deals himself with the Hydrozoa and Ctenophora, the Batrachia, the Sponges, and the Mollusca, together with additions to ethnography; whilst other groups have been entrusted to C. A. Paiva (aquatic Hemiptera), Col. J. Stephenson (aquatic Oligochæta), Dr. Asajiro Oka (Hirudinea), Sir Charles Eliot (Mollusca Nudibranchiata), Toköi Kaburaki (brackishwater Polyclads), and Stanley Kemp (Crustacea Decapoda and Stomatopoda). Numerous text-figures and five plates illustrate these contributions.

Dr. Annandale's paper on the Hydrozoa and Ctenophora is one of special interest, our knowledge of the Oriental fresh-water forms of these two groups being of rather recent date and, as the author observes, still very imperfect. A new Medusa is described under the name of Asenathia piscatoris, g. et sp. nn., from the tidal creeks containing water of low but extremely variable salinity in the vicinity of Port Canning, in the Gangetic Delta. It is referred to the family Olindiadidæ of Mayer (order Trachymedusæ), and is regarded as not improbably the sexual generation of the hydroid Annulella gemmata, Ritchie.

In the part devoted to the Batrachians, Dr. Annandale deals chiefly with the Oriental frogs of the groups of Rana tigrina, R. limnocharis, and R. Liebigii, as well as with the species clustering round $R$. Tytleri and $R$. erythraea; also with various tadpoles from Japan, China, the Malay Peninsula, Burma, and Ceylon. The author's views on $R$. tigrina have since been a subject of discussion between him and $\mathrm{Mr}$. Boulenger in the Records of the Indian Musrum, and further differences of opinion between the two authorities will shortly appear in a monograph of the Oriental species of Rana to be published by the Indian Museum.

The two marine Sponges (Reniera implexa, Schmidt, and Amorphinopsis excavans, Carter, var. n. Robinsonii) discussed by Dr. Annandale were found growing on the wooden piers of a landing-stage at Port Weld in Perak, Malay Peninsula, and their chief ethological interest lies in the fact that they grew immediately below high-tide level, and were, therefore, exposed daily for a considerable time to the air and to the heat of a tropical sun. Several new fresh-water Sponges from Japan, China, and the Malay Peninsula are described, and a list of the Spongillidæ of Asia, with synonyms, is appended.

Among the Mollusca the hybrid name Pseudovivipara for a new genus is a regrettable choice.

A paper in French is a revision of the fungi of the genus Nocandia, Toni and Trevisan, by Capt. Froilano de Mello and Dr. St. Antonio Fernandez, of the Portuguese India Bacteriological Service.

The Memoirs contain also a revision of the lizards of the genus Tachydromus, with two plates, by $\mathrm{Mr}$. G. A. Boulenger, in which this genus is shown to be very closely connected with Lacerta, instead of occupying a quite isolated position in the family to which it belongs, as hitherto believed. Two new genera are proposed under the names of Platyplacopus and Apeltonotus.

In the Journal and Proceedings. we have a paper by Baini Parshad on the seasonal conditions governing the pond-life in the Punjab. There are three papers on Mollusca: two by E. Vredenburg on the occurrence of Cypraea nivosa in the Mergui Archipelago, the only previously recorded habitat of this species beinss NO. 2640 , VOL. IO5]
Mauritius, and of Dolium variegatum at Mascat and Karachi, a species hitherto regarded as special to the living fauna of Australia, but recorded from the Pliocene of Java; and one by Dr. Annandale and B. Parshad on the taxonomic position of the genus Camptoceras and of Lithotis japonica. W. H. Phelps describes the weaving habits of the spider Cyrtophora citricola, and Maude L. Cleghorn has experiments on the vitality and longevity of silkworm moths during the cold and rainy seasons in Bengal.

Botany is represented by four contributions: Notes on the flora of the Anaimaly Hills, by C. Fisher; on the pollination of flowers, by $\mathrm{I}$. K. Burkill; on the Burmese sesamum varieties, their variation and growth, by A. McKerral; observations and experiments on the rust of Launaea asplenifolia, commonly known as Jangli Gobi, by Karm Chand Mehta; and on the constituents of the bark of Hymenodactyon excelsum, by C. L. Gibson and J. L. Simonsen.

\section{Attainment of High Levels in the Atmosphere.}

SCIENCE for March 19 has an article by Prof. Alexander McAdie, of Blue Hill Observatory, on "The Attainment of High Levels in the Atmosphere." A period of 135 years is dealt with, during which various methods and agencies have been employed for exploring the high levels of the atmosphere. Dr. John Jeffries crossed the English Channel in January, ${ }_{17} 85$, and attained a height of about 2012 metres, and in the following twenty years heights of more than 4000 metres were attained. In September, 1862, Glaisher and Coxwell reached a height of II,200 metres. Three other noteworthy records by manned balloons are mentioned. Tissandier, Spinetti, and Sivel, acting for the French Academy, attained a height of 8530 metres in April, 1875 ; Dr. A. Berson reached 9600 metres in December, 1894 ; and Berson and Süring in Igor attained a known elevation of I0,500 metres, and probably 10,800 metres, both men being unconscious at the higher level. Dealing with other than manned balloons, the extreme elevations noted are :--By kites, 7044 metres in 1907 ; by rigid dirigibles, 6200 metres in I9I7; by sounding balloons, 37,000 metres in 1912; and by pilot balloons, height determined by theodolite, 39,000 metres. The aeroplane record has rapidly advanced. In 1909 Latham made 161 metres, and Drexel in 1910 made 1829 metres. Prior to I9I4 the maximum height attained, according to Prof. McAdie, was 6000 metres by Perreyon in March, I9I3. The war gave a great impetus to the development of the aeroplane, and since the war, in February, I920, Major R. W. Schroeder, chief test pilot at Dayton, U.S.A., is stated to have attained 10,979 metres; in this ascent the oxygen-supply was exhausted. The ro- $\mathrm{km}$. level is the bottom of the stratosphere or isothermal region, and the top of the troposphere or convectional region-an exceedingly important elevation to meteorologists. Schroeder's thermograph indicated a minimum temperature of $-55^{\circ} \mathrm{C}$., or $99^{\circ}$ below the freezing point on the Fahrenheit scale.

In Science for April 9 Dr. J. G. Coffin, director of aeronautical research of the Curtiss Aeronautical and Motor Corporation, suggests that Prof. A. McAdie has sometimes accepted too readily unauthorised statements made in the Press as to altitudes reached. A criticism is made of expressing results without airtemperature correction, which is not only unsatisfactory, but also scientifically incorrect. The correction is the larger the colder the air encountered in the flight. It is pointed out that it is essential so far as possible for all concerned to work on the same un- 
biased scientific basis. Dr. Coffin, to bring out the importance of the air-temperature correction, assumes two cases, both with identically perfect barographs, with no instrumental errors, one ascent in summer and the other in winter to an altitude that both read 8 in. of mercury as the minimum pressure. He assumes that in the summer case the average temperature of the air is $10^{\circ} \mathrm{C}$., and in the winter $-30^{\circ} \mathrm{C}$., which values correspond closely to actually observed figures. The true altitudes of these are $33,475 \mathrm{ft}$. (10,203 m.) for the summer instance and $30,929 \mathrm{ft}$. ( $9427 \mathrm{~m}$.) for the winter, although the altitude uncorrected for air temperature is $36,020 \mathrm{ft}$. (10,979 m.) for both. Dr. Coffin states that the flight made by Roland Rohlfs, the test pilot of the Curtiss Engineering Corporation, on September I8, I919, attained an altitude of $34,910 \mathrm{ft}$. (10,640 m.), partially corrected, but uncorrected for the average temperature of the air column; the true altitude was $32,450 \mathrm{ft}$. ( $9890 \mathrm{~m}$.) corrected for air temperature. The altitude attained by Major Schroeder, similarly corrected for temperature, is $30,75 \mathrm{r} \mathrm{ft}$. (9373 m.).

In Science of April 3o, Prof. McAdie gives as approximate values, corrected for mean air column temperature, vapour pressure, gravity, altitude, and latitude: Rohlfs, 32,4I8 ft. (080.5 m.), and Schroeder, $3 \mathrm{x}, \mathrm{I} 84 \mathrm{ft}$. (9505 m.).

The Meteorological Magazine for March, in an article "The Highest Aeroplane Ascent," mentions Major Schroeder's ascent on February 27 last referred to above, and expresses the hope that it will be authenticated in due course. The record of Berson and Süring, who, it is stated, reached $35,400 \mathrm{ft}$. (10, $789 \mathrm{~m}$.) in a balloon on July $3 \mathrm{I}$, 190r, is mentioned as being generally accepted as the greatest height hitherto attained by aeronauts. The article seems to throw some doubt on the lowest temperature observed in the ascent by Glaisher and Coxwell.

\section{Physical Problems in Soil Cultivation. ${ }^{1}$}

$\mathrm{U}^{\mathrm{P}}$ to the outbreak of the war the farmer could generally rely upon an adequate supply of cheap labour. He had no great necessity to introduce labour-saving machinery into the routine of the farm. But the increasing demands of the Army for men and the menace of the submarine campaign brought him face to face with the difficult problem of growing more food with a greatly reduced staff. In such conditions the employment of machinery was the only solution, and although at the time it was introduced mainly as a temporary measure, it is now quite evident that economic conditions will cause it to be retained permanently. During the war the rate of progress in the industry of agriculture was necessarily forced above the normal, and the urgent need at the present time is to take stock of the position, so that future developments may be guided along the right lines. In this connection the report of the Departmental Committee of the Ministry of Agriculture on Agricultural Machinery appears at an opportune moment. The report deals with "the further steps which should be taken to promote the development of agricultural machinery," and, so far as tillage implements are concerned, falls naturally into two sections, dealing with (I) fundamental research on the physical properties of soil as affected by cultivation operations, and (2) the application of the knowledge thus gained to the design of new implements and the improvement of old ones.

1 Report of the Departmental Commit'ee of the Ministry of Agriculture on Agricultural Machinery. (H.M. Stationery Office.) Price Is. net. No. 2640 , VOL. I05]
Taking the second section first, the Committee lays great stress on the fact that all development in the design of machinery has proceeded on empirical lines. "Although searching questions were addressed to several witnesses, we could not discover that any real attempt had been made in the past to determine the principles which underlie the design of the variety of implements in use in modern farming." As a result an enormous number of patterns of the same implement are made, one manufacturer alone having more than two hundred and fifty patterns of plough. The Committee considers that much of this overlapping and wasted effort will be avoided when the Ministry of Agriculture sets up its projected Research Institute in Agricultural Machinery.

The first section-research into the physical properties of soil--is regarded, rightly, as of primary importance. "Progress in research as regards tillage implements must depend largely upon the results of investigations into soil physics and the problem of tilth." It is clearly pointed out that this research must not be pursued with the immediate object of obtaining "practical" results. A sound theory of the interesting but complicated physical phenomena shown by soil must first be built up. Once this is achieved, the practical deductions will follow almost automatically. The very nature of this work precludes the possibility of forcing the pace, but it is suggested that, as the work has been in progress for some time at Rothamsted, it should be further developed by the appointment of additional scientific assistants.

If this were done it would be possible to pay more attention to those physical problems concerned with the soil tilth than is practicable at present. Tilth is related to the production of compound particles or aggregates in the soil, and to the factors causing plasticity, cohesion, etc. At the same time a study of the mechanical action of the plough could be started having as its aim the specification of the design of mould-board to meet different soil conditions. This is an unsurveyed field and full of promise.

The report also deals with the educational and research work which should be carried out at the projected Research Institute in Agricultural Machinerv, especially from the engineering point of view. It also advocates the appointment of an Advisory Committee, composed of representatives from the research institutions, implement-makers, and agriculturists, to co-ordinate the whole of the work.

In the present article attention has been confined mainly to the sections dealing with the physical questions involved. The report covers a much wider field. It is closely reasoned and convincing, and can be cordially recommended to all concerned in the industry of agriculture.

B. A. KEEN.

\section{The Anomaly of the Nickel Iron Alloys: Its Causes and its Applications. ${ }^{1}$}

THE lecturer began by a reference to the work of John Hopkinson, and to his own early work on the perfecting of standards of length. His first experiments were on nickel, which had two great advantages over brass for metrological work, viz. its smaller coefficient of expansion and its greater freedom from corrosion. He would probably not have looked further but for the difficulty at the time of getting large bars of the material free from flaws. In investigating the

1 Abstract of the Fourth Guthrie Lecture delivered before the Phys"cal Society on April 23 by Dr. C. E. Guillaume. 